\section{Pyrite formation linked with hydrogen evolution under anaerobic conditions}

\author{
E. Drobner*, H. Huber*, G. Wächtershäuser†£, \\ D. Rose $\neq$ \& K. O. Stetter*
}

* Lehrstuhl für Mikrobiologie, Universität Regensburg,

Universitätsstrasse 31, D-8400 Regensburg, FRG

$\dagger$ Tal 29, D-8000 München 2, FRG

$\ddagger$ Staatliches Forschungsinstitut für Angewandte Mineralogie,

Kumpfmühlerstrasse 2, D-8400 Regensburg, FRG

THE formation of pyrite $\left(\mathrm{FeS}_{2}\right)$, an important factor in determining the global redox balance ${ }^{1}$, has recently attracted biological interest as a possible direct source of energy for early life $\mathrm{e}^{2-5}$. The theory implies that carbon dioxide fixation, in competition with hydrogen formation, can serve as the electron sink for pyrite formation and it seems to be supported by the detection of minute grains of pyrite and iron sulphides inside bacteria ${ }^{5-8}$. Yet it clashes with the conventional assumption that elemental sulphur or a sulphur equivalent (polysulphide or thiosulphate) is the mandatory oxidant for pyrite formation, ${ }^{90}$. It has been stressed that the reaction $\mathrm{FeS}+\mathrm{H}_{2} \mathrm{~S} \rightarrow \mathrm{FeS}_{2}+\mathrm{H}_{2}$ (with $\mathrm{H}^{+}$as the oxidant) has "never been observed ... during several years of experimentation"10. Here we report the formation of both pyrite and molecular hydrogen under fastidiously anaerobic conditions in the aqueous system of $\mathrm{FeS}$ and $\mathrm{H}_{2} \mathrm{~S}$.

Of the geochemical environments in which pyrite can form, two are of particular biological significance: sedimentary systems, in which pyrrhotite $\left(\mathrm{Fe}_{1-\mathrm{x}} \mathrm{S}\right)$ is extremely rare $^{11}$ and in which pyrite seems to be formed from amorphous $\mathrm{FeS}^{10,12}$, and hydrothermal systems in which pyrite may be formed not only from amorphous $\mathrm{FeS}$ but also from pyrrhotite ${ }^{11}$. We have modelled these by reacting aqueous $\mathrm{H}_{2} \mathrm{~S}$ at $100^{\circ} \mathrm{C}$ for 14 days, under strictly anaerobic and nearly neutral conditions, either with amorphous $\mathrm{FeS}$, precipitated from aqueous $\mathrm{FeSO}_{4}$, or with synthetic (metal basis) pyrrhotite. Our experiments show a linkage between pyrite formation (ascertained by $\mathrm{X}$-ray diffraction) and hydrogen evolution (determined by gas chromatography). Typical results are shown in Table 1 and in Figs 1-3. The pyrrhotite crystals (runs 1,2 ) seem to acquire a surface coating of pyrite as indicated by the hollow shells that remain if the

$\S$ To whom correspondence should be addressed.

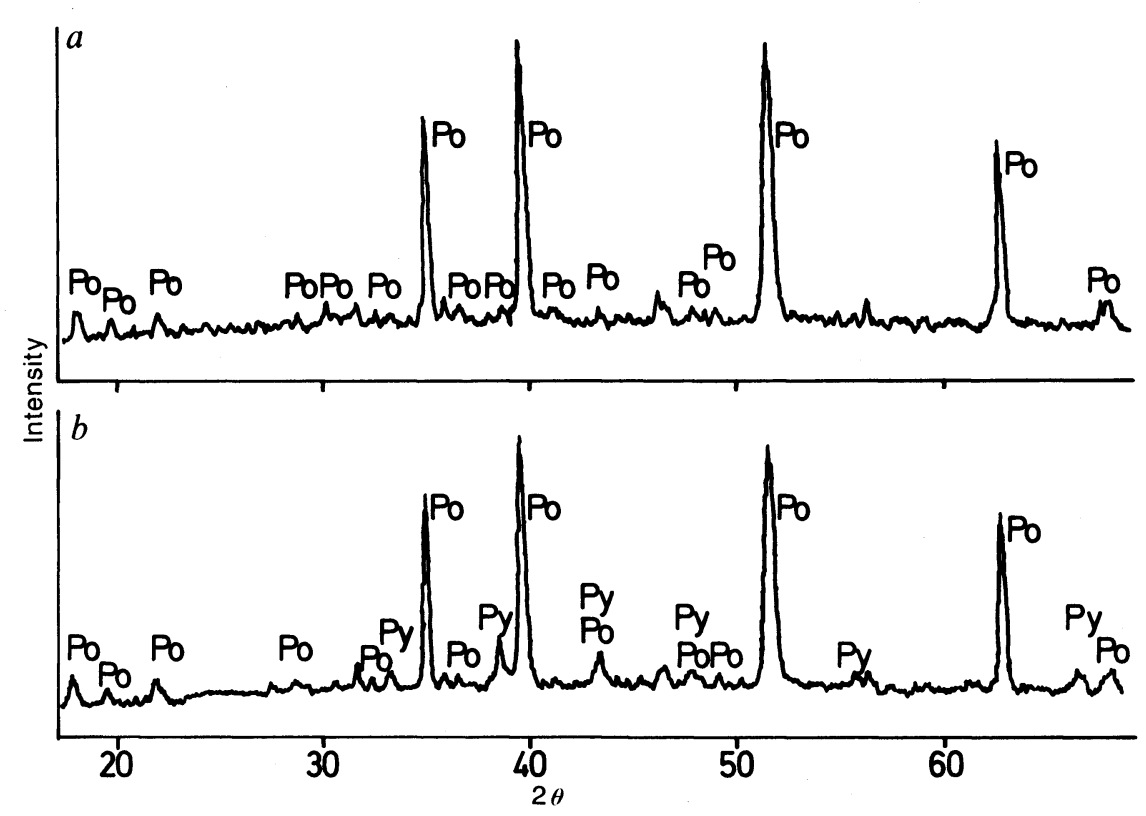

TABLE 1 Products of anaerobic FeS- $\mathrm{H}_{2} \mathrm{~S}$ systems

\begin{tabular}{|c|c|c|c|c|}
\hline \multirow[b]{2}{*}{ No. } & \multicolumn{2}{|l|}{ Starting materials } & \multicolumn{2}{|c|}{ Products after 14 days } \\
\hline & FeS & $\underset{(\mathrm{mmol})}{\mathrm{H}_{2} \mathrm{~S}}$ & 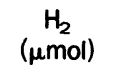 & Mineral products \\
\hline $\begin{array}{l}1 a \\
1 b\end{array}$ & $\begin{array}{l}\text { pyrrhotite 99\%* } \\
\text { (200 mg) }\end{array}$ & 2 & $\begin{array}{c}23 \pm 3.5 \\
0.25\end{array}$ & pyrite \\
\hline $\begin{array}{l}2 a \\
2 b\end{array}$ & $\begin{array}{l}\text { pyrrhotite } 99.99 \% * \\
(200 \mathrm{mg})\end{array}$ & $\frac{2}{-}$ & $\begin{array}{l}18 \\
0.2\end{array}$ & pyrite \\
\hline $\begin{array}{l}3 a \\
3 b\end{array}$ & $\begin{array}{l}\text { FeS amorphous, wet } \dagger \\
\text { (precipitated with } \\
\left.\mathrm{H}_{2} \mathrm{~S}\right)(2 \mathrm{mmol})\end{array}$ & 2 & $\begin{array}{c}15 \pm 4 \\
0\end{array}$ & pyrite + mackinawite \\
\hline $\begin{array}{l}4 a \\
4 b\end{array}$ & $\begin{array}{l}\text { FeS amorphous, dried } \ddagger \\
\mathrm{Na}_{2} \mathrm{~S}(200 \mathrm{mg})\end{array}$ & $\ddagger 2$ & $\begin{array}{c}40 \pm 2.5 \\
0.2\end{array}$ & $\begin{array}{c}\text { pyrite }+ \text { mackinawite } \\
-\end{array}$ \\
\hline 5 & - & 2 & 0.2 & - \\
\hline 6 & - & - & 0 & - \\
\hline
\end{tabular}

All procedures were carried out under $\mathrm{CO}_{2}$. The solutions were prepared from doubly distilled water, through which $\mathrm{N}_{2}-\mathrm{CO}_{2}$ had been bubbled for $2 \mathrm{~h}$. Serum bottles $(120 \mathrm{ml})$ were charged with the suspension of $\mathrm{FeS}$, stoppered and supplied with a $\mathrm{N}_{2}-\mathrm{CO}_{2}$ atmosphere $(80: 20,100 \mathrm{kPa})$ and then charged with an injection of $2 \mathrm{mmol}_{2} \mathrm{~S}$ gas and adjusted to $\mathrm{pH} 6.5$ with $\mathrm{NaOH}$. The $\mathrm{H}_{2} \mathrm{~S}$ gas was prepared by adding $50 \% \mathrm{H}_{2} \mathrm{SO}_{4}$ to $\mathrm{Na}_{2} \mathrm{~S} \cdot 9 \mathrm{H}_{2} \mathrm{O}$ in an evacuated serum bottle. During incubation for $14 \mathrm{~d}$ at $100^{\circ} \mathrm{C}$ in a rotary shaker (100 r.p.m.), the serum bottles were kept in anaerobic cylinders with an $\mathrm{N}_{2}-\mathrm{CO}_{2}$ atmosphere $(80: 20,180 \mathrm{kPa}) . \mathrm{H}_{2}$ was determined by gas chromatography (Hewlett Packard 5890). A packed column filled with Molecular Sieve 5A (Supelco) was used (injection temperature, $190^{\circ} \mathrm{C}$; oven temperature, $140^{\circ} \mathrm{C}$; detection temperature, $220^{\circ} \mathrm{C}$; carrier gas, $\mathrm{N}_{2}$ ). For runs 1,3 and 4, the averages and the standard deviations of the $\mathrm{H}_{2}$ measurements of three repeats of the reaction are given. Run 2 was not repeated. The traces of $\mathrm{H}_{2}$ in control runs $1 b, 2 b$ and $4 b$ are barely above the background (detection limit $0.1 \mu \mathrm{mol}$ ) and may be due to the reaction $2 \mathrm{FeS}+2 \mathrm{H}^{+} \rightarrow \mathrm{FeS}_{2}+\mathrm{Fe}^{2+}+\mathrm{H}_{2}$. In control run 5 , the trace of $\mathrm{H}_{2}$ may be due to thermal decomposition $\left(\mathrm{H}_{2} \mathrm{~S} \rightleftharpoons \mathrm{H}_{2}+\mathrm{S}\right)$. The solid phase was dried in an anaerobic chamber $\left(\mathrm{N}_{2}: \mathrm{H}_{2}=95: 5\right)$ and the mineral composition was analysed by $\mathrm{X}$-ray diffraction.

* Pyrrhotite (99\% or $99.99 \%$ ) (Johnson Matthey) was suspended in $10 \mathrm{ml}$ $\mathrm{H}_{2} \mathrm{O}$. Both pyrrhotites were free of elemental iron as indicated by the lack of hydrogen evolution upon dissolution in concentrated $\mathrm{HCl}$.

$\dagger$ Amorphous wet FeS was precipitated directly in the serum bottles used in the experiment by adding $2 \mathrm{mmol} \mathrm{H}_{2} \mathrm{~S}$ gas to $10 \mathrm{ml} 0.2 \mathrm{M} \mathrm{FeSO}_{4}$ which had previously been freed of $\mathrm{Fe}^{3+}$ by treatment with elemental zinc at $60^{\circ} \mathrm{C}$ for $2 \mathrm{~h}$.

$\mp$ Amorphous, dried FeS was prepared in an anaerobic chamber by adding $\mathrm{Na}_{2} \mathrm{~S} \cdot 9 \mathrm{H}_{2} \mathrm{O}(130 \mathrm{~g})$ to $0.6 \mathrm{M} \mathrm{FeSO}_{4}$ that had not been freed of $\mathrm{Fe}^{3+}$ filtering the precipitate, washing it with $\mathrm{H}_{2} \mathrm{O}$ and drying it under $\mathrm{CO}_{2}$. The dried precipitate was suspended in $10 \mathrm{ml} \mathrm{H}_{2} \mathrm{O}$.
FIG. 1 X-ray diffraction pattern of pyrrhotite (99\%; Johnson Matthey). a, Starting material. $b$, After incubation at $100{ }^{\circ} \mathrm{C}$ for $14 \mathrm{~d}$ in aqueous solution in the presence of $\mathrm{H}_{2} \mathrm{~S}$. Po, pyrrhotite; Py, pyrite; $2 \theta$, angle of reflection for Co $\mathrm{K} \alpha$ radiation. 


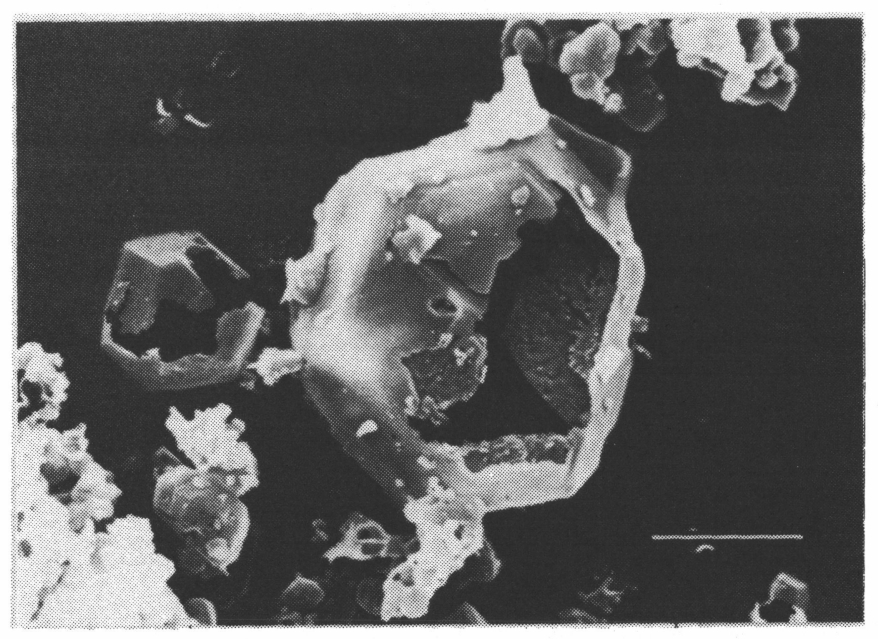

FIG. 2 Scanning electron micrograph of pyrite shells with pyrrhotite pseudomorphy (run 1a) after dissolution of pyrrhotite by treatment with $6 \mathrm{~N}$ $\mathrm{HCl}$. Scale bar, $0.5 \mu \mathrm{m}$.

pyrrhotite is leached out with $\mathrm{HCl}$ (Fig. 2). Amorphous FeS, precipitated in the absence of $\mathrm{Fe}^{3+}$ and of sulphur or sulphur equivalents (run 3), seems to produce pyrite in the form of discrete crystals (Fig. 3 ) as well as some mackinawite $\left(\mathrm{FeS}_{1-x}\right)$. Hydrogen evolution is also observed with an amorphous $\mathrm{FeS}$ precipitated with $\mathrm{Na}_{2} \mathrm{~S} \cdot 9 \mathrm{H}_{2} \mathrm{O}$ (containing polysulphide) without removing $\mathrm{Fe}^{3+}$ (run 4).

The results may best be represented by the following overall reactions

$$
\begin{aligned}
\mathrm{FeS}+\mathrm{H}_{2} \mathrm{~S} & \rightarrow \mathrm{Fe}(\mathrm{SH})_{2} \\
\mathrm{Fe}(\mathrm{SH})_{2} & \rightarrow \mathrm{FeS}_{2}+\mathrm{H}_{2}
\end{aligned}
$$

The reaction mechanism may be a concerted four-centre reaction with a simultaneous formation of the covalent bonds of $\mathrm{H}_{2}$ and $\mathrm{S}_{2}^{2-}$, but radical or hydride involvement cannot be excluded. The reaction of pyrrhotite seems to be a surface redox reaction with a concomitant rearrangement of the $\mathrm{S}^{2-} / \mathrm{S}_{2}^{2-}$ lattice and a diffusion of ferrous ions. The electron transfer may well be promoted by the semiconductor properties of pyrite.

The considerable variety of geochemical environments that give rise to pyrite may indicate a variety of pyrite-forming pathways using different oxidants. By contrast, the conventional assumption that pyrite formation requires not only $\mathrm{H}_{2} \mathrm{~S}$ (for $\mathrm{FeS}$ formation) but also elemental sulphur or polysulphide as the oxidant placed severe restrictions on the possible geochemical explanations of pyrite formation. In particular, it was difficult to explain sedimentary pyrite formation under anaerobic conditions. For example, Boesen and Postma ${ }^{12}$ demonstrated that the freshwater Ancylus clay in the Gotland deep of the Baltic Sea (deposited 9,200-7,700 years ago) is presently being sulphidized by the downward diffusion of $\mathrm{H}_{2} \mathrm{~S}$ from the overlying marine muds. In this process the ferrous ions in the clay are first converted into $\mathrm{FeS}$ and subsequently into $\mathrm{FeS}_{2}$. On this conversion they comment "... unless a hitherto unknown oxidant exists the only explanation seems to be either downward diffusion of polysulfides or that the $\mathrm{FeS} / \mathrm{FeS}_{2}$ distribution reflects a historical change [of the redox conditions]. The latter possibility seems, however, unlikely ...." Our results show that the system FeS$\mathrm{H}_{2} \mathrm{~S}$ is a powerful reducing agent and that $\mathrm{H}^{+}$can indeed serve as oxidant for pyrite formation. Thus, the somewhat implausible assumption of a slow diffusion of metastable polysulphides in, for example, the sediments of the Gotland deep is no longer required.

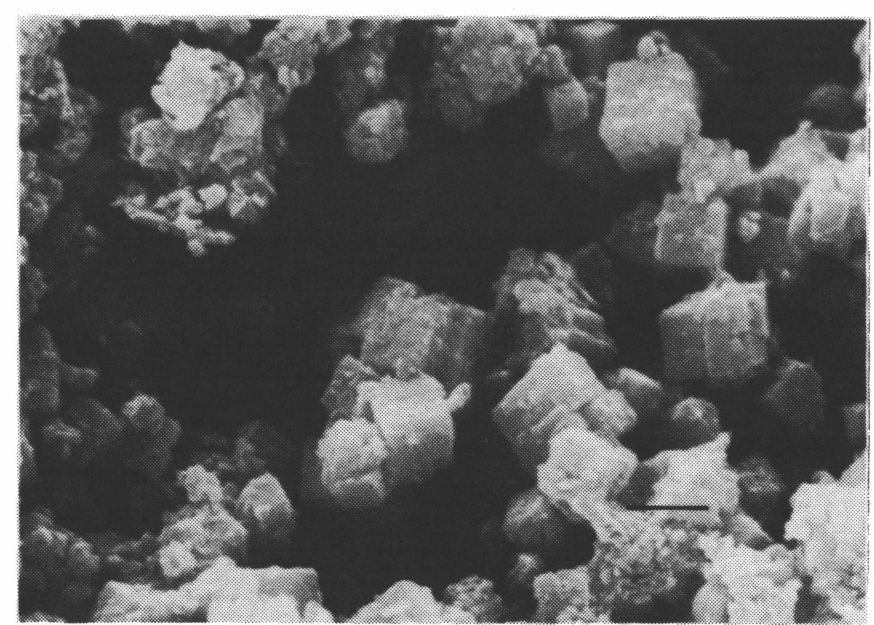

FIG. 3 Scanning electron micrograph of cubic pyrite crystals formed from amorphous FeS (run 4a). Scale bar, $1 \mu \mathrm{m}$.

The pyritization of fossils is also a highly variable and complex process. For some of these pyritization processes, our results seem to offer straightforward explanations if we assume: (1) diffusion of dissolved ferrous ions and $\mathrm{H}_{2} \mathrm{~S}$, at concentrations too small for $\mathrm{FeS}$ precipitation (at lower $\mathrm{pH}$, for example) into the site of fossilization; (2) the formation of $\mathrm{FeS}_{2}$ and $\mathrm{H}_{2}$ under the $\mathrm{pH}$ conditions of the site of fossilization; (3) the diffusion of $\mathrm{H}_{2}$ out of the site of fossilization. As a variation of this scheme, we may assume diffusion of sulphate ions into the site of fossilization and the formation of hydrogen sulphide by organotrophic sulphate-reducing bacteria at the site of fossilization. In any case, the implausible assumption of a conversion of hydrogen sulphide into elemental sulphur ${ }^{13}$ under the reducing conditions at the site of fossilization is no longer necessary.

The production of $\mathrm{H}_{2}$ in nature has previously been attributed to biogenic origins, geothermal exhalations and tropospheric decompositions ${ }^{14}$. Our results establish the system $\mathrm{FeS}-\mathrm{H}_{2} \mathrm{~S}$ as an alternative source of hydrogen. This source is ubiquitous, which correlates well with the ubiquitous occurrence of hydrogen-consuming bacteria, such as methanogens, sulphur and sulphate reducers and hydrogen-oxidizing bacteria. Finally, our findings suggest that a functional evolutionary connection might exist between the hydrogen-producing system $\mathrm{FeS}-\mathrm{H}_{2} \mathrm{~S}$ and the hydrogen-producing iron-sulphur centres of hydrogenases and nitrogenases.

Received 26 April; accepted 10 July 1990.

1. Jorgensen, B. in Autotrophic Bacteria (eds Schlegel, H. G. \& Bowien, B.) 117-146 (Science Tech, Madison, 1989).

2. Wächtershäuser, G. Syst. appl. Microbiol. 10, 207-210 (1988).

3. Wächtershäuser, G. Microbiol. Rev. 52, 452-484 (1988).

4. Wächtershäuser, G. Proc. natn. Acad. Sci. U.S.A. 87, 200-204 (1990).

5. Popper, K. R. Nature 344, 387 (1990).

6. Farina, M., Esquivel, D. M. S. \& Lins de Barros, H. G. P. Nature 343, 256-258 (1990).

7. Mann, S., Sparks, N. H. C., Frankel, R. B., Bazylinski, D. A. \& Jannasch, H. W. Nature 343, 258-261 (1990).

. Williams, R. J. P. Nature 343, 213-214 (1990).

9. Roberts, W. M. B., Walker, A. L. \& Buchanan, A. S. Miner. Deposita 4, 18-29 (1969).

9. Roberts, W. M. B., Walker, A. L. \& Buchanan, A.
10. Berner, R. A. Am. J. Sci. 268, 1-23 (1970).

10. Berner, R. A. Am. J. Sci. 268, 1-23 (1970).
11. Hall, A. J. Miner. Mag. 50, 223-229 (1986).

12. Boesen, C. \& Postma, D. Am. J. Sci. 288, 575-603 (1988)

13. Allison, P. A. in Palaeobiology (eds Briggs, D. E. G. \& Crowther, P. R.) 253-255 (Blackwell Scientific, Oxford, 1990).

14. Schlegel, H. G. in Autotrophic Bacteria (eds Schlegel, H. G. \& Bowien, B.) 305-330 (Science Tech, Madison 1989).

ACKNOWLEDGEMENTS. We thank L. Schwarzfischer-Pfeilschifter for technical assistance and $\mathrm{K}$. Popper for improvements of the presentation. This work was supported by the Bundeministerium für Forschung und Technologie and the Fonds der Chemischen Industrie. 